Науковий вісник НЛтУ України
Scientific Bulletin of UNFU
https://nv.nltu.edu.ua
$\begin{aligned} & \text { https://doi.org/10.15421/40280718 } \\ & \text { Article received 11.09.2018 p. } \\ & \text { Article accepted 26.09.2018 p. } \\ & \text { удк 911.3:504.4 }\end{aligned}$

T. М. Коткова, М. I. Федючка, I. Ф. Карась

Житомирський національний агроекологічний університет, м. Житомир, Украӥна

\title{
ЕКОЛОГІЧНА ОЦІНКА ПИТНОЇ ВОДИ ЛУГИНСЬКОГО РАЙОНУ ЖИТОМИРСЬКОЇ ОБЛАСТІ НА ВМІСТ ХЛОРИДІВ, СУЛЬФАТІВ ТА НІТРАТІВ
}

\begin{abstract}
Здійснено екологічну оцінку стану води водогонів та колодязів Лугинського району Житомирської області на вміст хлоридів, сульфатів та нітратів. Здійснено моніторинг ситуації в тих населених пунктах, де $\epsilon$ і водогін, і колодязі. Сюди належать смт Лугини, села Великий Дивлин, Липники, Червона Волока, Миролюбів (стара назва Жовтневе). Проведено низку досліджень за 2014, 2015, 2016 рр. У динаміці досліджуваних років встановлено тенденцію до збільшення вмісту забруднювачів групи кислотних залишків як у джерелах централізованого, так і децентралізованого водопостачання. Другою встановленою закономірністю виявився збільшений вміст усіх досліджуваних забруднювачів у колодязях порівняно 3 водогонами. Однак, якщо для хлоридів та сульфатів перевищень норм ДСанПІН 2.2.4-171-10 не виявлено, то вміст нітратів у деяких досліджуваних зразках був вищим за норму впродовж усіх досліджуваних років. Пояснити ситуацію можна зменшенням водності річок протягом останніх років та пониженням рівня підгрунтових вод, що призводить до збільшення концентрації усіх забруднювальних речовин, зокрема і нітратів. Особливо критичною ситуація була влітку 2016 р. У криницях деяких господарів води не було взагалі. Отже, не можна стверджувати, що ситуація з питним водопостачанням Лугинського району Житомирської області є безпечною. У посушливі роки, а саме такими були досліджувані, стаються спалахи забруднення питної води нітратами.
\end{abstract}

Ключові слова: забруднення води; державні санітарні норми; ДСТУ 7525:2014; джерела централізованого водопостачання; джерела децентралізованого водопостачання; колодязна вода; водопровідна вода.

Вступ. Вода на землі народилась разом з планетою Земля. Вона виявилась невід'ємною складовою частиною складної комбінації, в якій виникло життя. Саме вода - це єдина речовина на Землі, що є унікальним середовищем, яка зв'язує живу і неживу матерії (Honcharuk, 2018). Негативно впливають на здоров'я людини такі іони, що можуть міститися у воді, як хлориди $\left(\mathrm{Cl}^{-}\right)$, сульфати $\left(\mathrm{SO}_{4}^{--}\right)$, фториди $\left(\mathrm{F}^{-}\right)$, нітрати $\left(\mathrm{NO}_{3}^{-}\right)$(Holian, 2017; Honcharuk, 2018).

Гігієнічне значення хлоридів визначається їх походженням. У разі високого вмісту хлоридів у питній воді

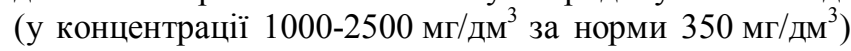
відбувається інтенсивне та довготривале напруження видільної функції організму, зокрема посилюється реабсорційна та фільтрувальна властивість нирок, активізуються гормональні процеси, що пов'язані з розподіленням хлориду натрію в організмі між позаклітинною рідиною та кров'ю. Тому дуже важливо знати та контролювати вміст цих речовин у воді (Holian, 2017; Honcharuk et al., 2018; Fadeeva, 1972).

Не менш шкідливими є сульфати. Вміст сульфатів у природних водах змінюється в широких межах (від часток міліграма до кількох грамів на літр) і зумовлено вимиванням солевмісних порід або скиданням у водойми

промислових і побутових стічних вод (Bobrovskyi, 2005; GOST 4192-82, 2003). Наявність у воді сульфатів понад 500 мг/л надає їй солонуватий присмак і призводить до порушення роботи травної системи у людей (GOST 18826-73, 2003; National Report, 2011).

Головним джерелом сульфатів у поверхневих водах $\epsilon$ процеси хімічного вивітрювання і розчинення сірковмісних мінералів, в основному гіпсу, а також окислення сульфідів і сірки:

$$
\begin{gathered}
2 \mathrm{FeS}_{2}+7 \mathrm{O}_{2}+2 \mathrm{H}_{2} \mathrm{O}=2 \mathrm{FeSO}_{4}+2 \mathrm{H}_{2} \mathrm{SO}_{4} ; 2 \mathrm{~S}+3 \mathrm{O}_{2}+ \\
2 \mathrm{H}_{2} \mathrm{O}=2 \mathrm{H}_{2} \mathrm{SO}_{4} .
\end{gathered}
$$

Значні кількості сульфатів надходять у водойми у процесі відмирання організмів, окислення наземних i водних речовин рослинного і тваринного походження і 3 підземним стоком (HDK, 1991; DSTU ISO 4808, 2007; Korotun, 2018). Проте найбільше води забруднюються нітратами. Нітрати містяться переважно у поверхневих водах. Нітрати в концентрації понад 20 мг/л здійснюють токсичну дію на організм людини. Постійне вживання води 3 підвищеним вмістом нітратів призводить до захворювань крові, серцево-судинної системи, спричиняє метгемоглобінемію у дітей (National Report, 2011).

Аналіз останніх публікацій. У середині XIX ст. вперше у світі було використано хлор для знезараження

Інформація про авторів:

Коткова Тетяна Миколаївна, канд. с.-г. наук, доцент. Email: tetjana.kotkova@gmail.com

Федючка Микола Ілліч, канд. с.-г. наук, доцент. Email: mif_1963@ukr.net

Карась Ірина Федорівна, канд. с.-г. наук, доцент. Email: iraver@ukr.net

Цитування за ДСтУ: Коткова Т. М., Федючка М. І., Карась І. Ф. Екологічна оцінка питної води Лугинського району Житомирської області на вміст хлоридів, сульфатів та нітратів. Науковий вісник НлтУ України. 2018, т. 28, № 7. С. 83-87.

Citation APA: Kotkova, T. N., Fedjuchka, N. I., \& Karas, I. F. (2018). Environmental assessment of drinking water in Luhyny district of Zhytomyr region on chlorides, sulphates and nitrates content. Scientific Bulletin of UNFU, 28(7), 83-87.

https://doi.org/10.15421/40280718 
води від холери та чуми. У 1870 р. німецький вчений бактеріолог Роберт Кох запропонував обробляти питну воду для боротьби з епідемією холери піпохлоридом натрію. У 1914 р. у США було прийнято Національний державний стандарт (зараз він містить 102 показники), а в 1937 p. у СССР також розробили державний стандарт (Honcharuk, 2018; Honcharuk et al., 2018). Це були перші два стандарти в світі, удосконалення яких триває дотепер. Наявні на сьогодні технології оброблення і знезараження води і стандарти на водогінну воду абсурдні та аморальні! Хлорування первинної природної води призводить до утворення гігантської дози супертоксичних хлорорганічних сполук. що важко виділяються в лабораторіях станції водопідготовки, призводять аж до утворення діоксинів, які присутні в багатьох водогонах світу (Honcharuk, 2018; Honcharuk et al., 2018; Hryhorenko, Shevchenko \& Dziak, 2012).

Аналіз водопровідних систем у таких містах світу, як Москва, Київ, Париж, Нью-Йорк, Тель-Авів та ін., показав, що практично скрізь використовують технологію інтенсивного хлорування. При цьому формально якість води відповідає стандартам ВООЗ. Дослідження науковців Інституту колоїдної хімії та хімії води ім. А. Думанського свідчать про те, що вимоги ВООЗ давно застарілі й не можуть у принципі відображати реальний стан систем водозабезпечення. Вода у водогонах всюди піддається біообростанню, виявляються некультурабельні форми мікрофлори, аж до поширення в природі представників мікроскопічних грибів роду Penicillium - дуже токсичного для людини (Honcharuk, 2018; Honcharuk et al., 2018).

Під час знезаражування хлором у воді утворюються тисячі супертоксичних сполук, 3 яких найнебезпечніші - хлорорганічні, що мають, крім яскраво вираженої токсичності, мутагенність та канцерогенність. Подальше очищення за допомогою активованого вугілля видаляє не всі з них (Hryhorenko, Shevchenko \& Dziak, 2012; Fadeeva, 1972). 32014 p. діє стандарт на питну воду ДСТУ 7525:2014 (DSTU ISO 7525, 2014).

Щодо підвищеного вмісту нітратів, то такий спричиняє водно-нітратну метгемоглобінемію. Водно-нітратна метгемоглобінемія зумовлена токсичною дією нітратів, яка полягає у кисневому голодуванні тканин (гіпоксії), що розвивається внаслідок порушення транспортування кисню кров'ю, а також у пригніченні активності ферментних систем, що беруть участь у процесах тканинного дихання (Khilchenko, 2018).

Варто наголосити, що 3 року в рік збільшується кількість проб води, забрудненої нітратами. Фахівці ДУ "Київський ОЛЦ ДСЕСУ" та відокремлені структурні підрозділи у 2013 р. зафіксували 8 випадків перевищення вмісту нітратів у питній воді $(2-$ в Яготинському; 1 - в Києво-Святошинському; 1 - в Миронівському; 2 в Рокитнянському; 2 - в Тетіївському районах). 3 2162 проб води криниць, досліджених у 2013 р., перевищення залишкових концентрацій нітратів виявлено в 688 пробах (31,8 \%). Найбільше проб з перевищенням гігієнічного нормативу виявлено в Білоцерківському, Миронівському, Рокитнянському, Таращанському, Сквирському, Фастівському районах. У 2014 р. досліджено 834 проби, з них перевищення залишкових концентрацій нітратів виявлено в 295 (35,4 \%) пробах. Найбільше проб з перевищенням гігієнічного нормативу виявлено в Миронівському, Сквирському та Фас- тівському районах (Methemoglobinemia, 2018). Подібна ситуація спостерігалася і в Кіровоградській області (Rilova, 2002). Схожі результати моніторингу отримали i на Тернопільщині (Blazhkevych, 2018). За 6 місяців 2017 р. Красилівське районне лабораторне відділення Державної установи "Хмельницький обласний лабораторний центр МО3 України дослідило 183 проби води на вміст нітратів (вживають діти до 3-х років), з них не відповідає нормативним вимогам 53 проби, що становить 29 \% (Shkrabliuk, 2018). Подібні моніторингові дані отримано у наших публікаціях (Kotkova, Seleznova \& Kotkov, 2011; Kotkova, Seleznova \& Yurchuk, 2013).

У країнах Євросоюзу ситуація дещо краща. Однак трапляються випадки забруднення вод, особливо грунтових. Так, з'ясовано, що 18 \% грунтових вод у Німеччині в окремі роки не відповідає застосовному порогу 50 млг нітратів на літр (Trinkwasser, 2018). Трапляються окремі випадки забруднення вод і в інших регіонах (Schadstoffe, 2018; Wasser, 2018).

Методи проведення дослідження. У процесі досліджень було задіяно польовий метод (відбір проб води) та лабораторний (дослідження вмісту сполук у пробах. Для встановлення вмісту досліджуваних сполук у пробах води застосовували стандартні методики, зокрема: методи визначення азотовмісних речовин. Методи визначення нітратів (ГОСТ 18826-73. Методы определения нитратов. Колориметрический метод с салициловокислым натрием) (GOST 18826-73, 2003); методи визначення вмісту хлоридів. (ГОСТ 4245-72. Методы определения содержания хлоридов. Метод титрометрический) (GOST 4245-72, 2003); методи визначення сульфатів (ГОСТ 4389-72. Методы определения сульфатов. Метод турбидиметрический) (GOST 4389-72, 2003).

Результати дослідження. За результатами встановлення якості питної води джерел централізованого та децентралізованого водопостачання Лугинського р-ну Житомирської обл. визначено вміст хлоридів (рис. 1). Упродовж 2014-2016 рр. перевищень ДСанПіН 2.2.4171-10 та ДСТУ 7525:2014 для цих сполук не виявлено у жодному з досліджуваних зразків. Проте більшою концентрація хлоридів була у воді колодязів порівняно 3 водогонами (Maliarenko, 2014; Hygienic requirements, 2010; Lure, 1973).

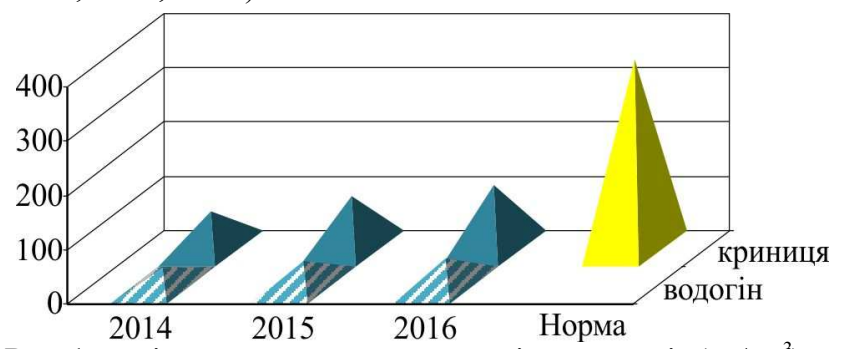

Рис. 1. Порівняльна характеристика вмісту хлоридів (мг/дм $\left.{ }^{3}\right)$ у воді питній централізованого та децентралізованого водопостачання Лугинського району Житомирської області (20142016 pp.) $(n=5)$

У динаміці 2014-2016 рр. відбувалася тенденція до збільшення вмісту хлоридів як у воді колодязів, так і водогонів. Високий вміст хлоридів у воді можливий, як у разі проходження водоносного горизонту через солончакові грунти, так і в разі забруднення вод стічними водами різного походження (кухонними відходами та помиями, екскрементами людей та тварин, сечею тощо). Оскільки в Лугинському районі немає солончако- 
вих грунтів, то наявність хлоридів пов'язана із надходженням до водоносних пластів відходів саме органічного походження. При цьому перевищення норм ДСанПіН 2.2.4-171-10 не виявлено.

Окрім цього, показниками забруднення вод є наявність сульфатів - солей сульфатної кислоти. Основним складником сульфатів $\epsilon$ сірка, яка $є$ складовою частиною білкових тіл. Під час розкладання та подальшого окислення сірка перетворюється у солі сульфатної кислоти, які далі потрапляють до підземних вод, а звідти до мережі питного водопостачання. Саме тому підвищується вміст сульфатів у питній воді, що призводить до розладу кишково-шлункового тракту, оскільки ці речовини погано всмоктуються кишечником. Якщо вміст сульфатів у воді питній досягає 1000 мг/дм та вище, відбувається порушення секреторної діяльності шлунку, процеси всмоктування та перетравлення їжі.

Здійснили порівняльну характеристику вмісту сульфатів у питній воді централізованого та децентралізованого водопостачання (рис. 2).

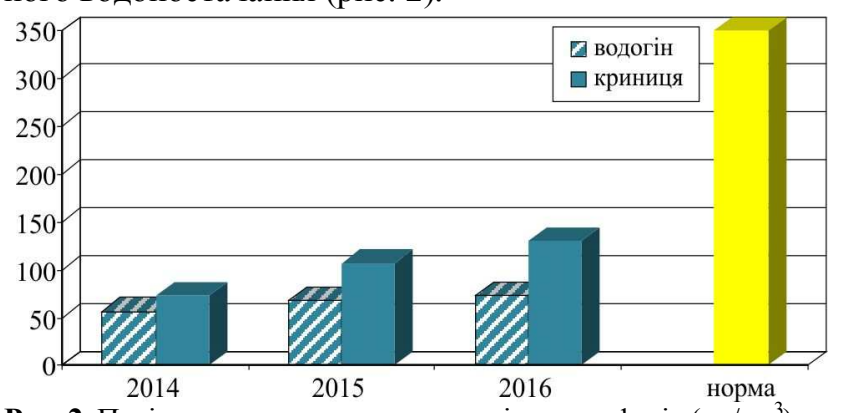

Рис. 2. Порівняльна характеристика вмісту сульфатів (мг/дм³) у воді питній централізованого та децентралізованого водопостачання Лугинського району Житомирської області (2014-2016рр.) $(n=5)$

Результати дослідження свідчать про те, що як і у попередньому випадку, вміст сульфатів був більшим у колодязній воді, порівняно з водогінною, зокрема у 1,22,0 рази. Загалом перевищень норм ДСанПіН 2.2.4-17110 та ДСТУ 7525:2014 для сульфатів не виявлено. У динаміці досліджуваних років встановлено тенденцію до незначного збільшення вмісту цих сполук у питній воді району.

Отже, можемо стверджувати, що вміст хлоридів та сульфатів у пробах води залежав від мережі водопостачання та був більшим саме у колодязній воді. Якщо вміст хлоридів та сульфатів у питній воді Лугинського p-ну Житомирської обл. перебував у межах норми, то вміст нітратів, навпаки, перевищує допустимі значення.

У динаміці 2014-2016 рр. збільшував вміст нітратів у воді джерел як централізованого, так і децентралізованого водопостачання. Пояснити цю ситуацію можна зменшенням водності річок упродовж останніх років та пониженням рівня підгрунтових вод, що призводить до збільшення концентрації усіх забруднювальних речовин, зокрема і нітратів (рис. 3).

Аналіз результатів моніторингу свідчить про те, що у питній воді колодязів забруднення нітратами було більшим в 1,7 раза, ніж у водогонах. У пробах води, відібраної з водогонів, виявлено лише один зразок води 3 перевищенням норм нітратів (2016 р. - с. Липники). У питній воді колодязів проби забрудненої води відбирали регулярно. Детальний аналіз кількості забруднених зразків води за вмістом нітратів у воді колодязів у 2014 р. наведено в табл. 1.

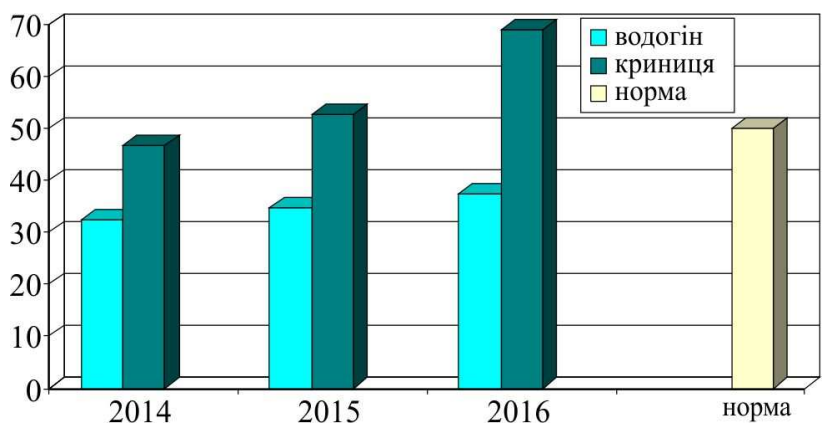

Рис. 3. Порівняльна характеристика вмісту азоту нітратного у питній воді централізованого та децентралізованого водопостачання Лугинського району Житомирської області (2014-2016рр.) $(n=5)$

Табл. 1. Кількість перевищень ДСанПІН 2.2.4-171-10 та

ДСТУ 7525:2014 для азоту нітратного у пробах питної води Лугинського району в 2014 р. $(n=5)$

\begin{tabular}{|l|c|c|c|c|}
\hline \multirow{2}{*}{ Назва населеного пункту } & \multicolumn{4}{|c|}{ Децентралізоване водопостачання } \\
\cline { 2 - 5 } & Зима & Весна & Літо & Осінь \\
\hline смт. Лугини & - & 1 & 1 & 1 \\
\hline с. Миролюбів (Жовтневе) & - & 1 & 1 & - \\
\hline с. Великий Дивлин & - & - & 2 & - \\
\hline с. Липники & - & 1 & 1 & - \\
\hline с. Червона Волока & - & - & 1 & - \\
\hline
\end{tabular}

У 2014 р. було виявлено всього десять зразків води, відібраної $з$ колодязів досліджуваних сіл Лугинського p-ну, у яких вміст нітратів перевищував нормативи. Серед них були три зразки води, відібраної в смт Лугини (по одному навесні, влітку та взимку), два зразки води, відібраної в с. Миролюбів (по одному навесні та влітку), два зразки води, відібраної влітку в с. В. Дивлин, дві проби - у с. Липники та одну - у с. Червона Волока.

Сприятливішу ситуація 3 водою водогонів можна пояснити захищеністю іiі від зовнішнього забруднення. Здійснили аналогічні дослідження й у 2015 р. Їх результати наведено у табл. 2.

Табл. 2. Кількість перевищень ДСанПІН 2.2.4-171-10 та ДСТУ 7525:2014 для азоту нітратного у пробах питної води Лугинського району в 2015 р. $(n=5)$

\begin{tabular}{|l|c|c|c|c|}
\hline \multirow{2}{*}{ Назва населеного пункту } & \multicolumn{4}{|c|}{ Децентралізоване водопостачання } \\
\cline { 2 - 5 } & Зима & Весна & Літо & Осінь \\
\hline смт Лугини & & 1 & 1 & 1 \\
\hline с. Миролюбів (Жовтневе) & & 1 & & \\
\hline с. Великий Дивлин & 1 & & 2 & \\
\hline с. Липники & & 1 & 1 & 1 \\
\hline с. Червона Волока & & 1 & 1 & 1 \\
\hline
\end{tabular}

Всього у 2015 р. було виявлено 13 зразків води з перевищенням норм ДСанПіН 2.2.4-171-10 та ДСТУ 7525:2014. Серед них три зразки води, відібраної в смт Лугини (по одному навесні, влітку та восени), один зразок, відібраний навесні в с. Миролюбів, три зразки - в с. Великий Дивлин (один - взимку, два - влітку), по три зразки води, відібраної в с. Липники та Червона Волока (по одному у сезон, окрім зими).

Ще критичнішою стала ситуація у 2016 р. У деяких досліджуваних раніше колодязях влітку води взагалі не було (!). Здебільшого це явище спостерігали на підвищених елементах рельєфу. Таку ситуацію можна пояснити цілковитою відсутністю опадів упродовж майже всього літа. Це вже є екологічною катастрофою для Полісся. У другій половині літа населення Лугинського рну, що користується колодязями для питного водозабезпечення, не мало води для господарсько-побутового використання та напування худоби. Та ж вода, що залишилася, не завжди відповідала санітарним нормам. 
У 2016 р. також здійснили аналогічні дослідження проб води на вміст нітратів (табл. 3). У тих криницях, де влітку 2016 р. вода ще залишилась, ії рівень знизився до мінімуму, що призвело до збільшення випадків перевищення норм вмісту нітратів у воді децентралізованого водопостачання. Таких зразків було виявлено аж 18. Із них - чотири зразки 3 перевищенням норм ДСанПІН 2.2.4-171-10 та ДСТУ 7525:2014 було відібрано в смт Лугини (по одному - навесні та восени і два зразки влітку), два зразки в с. Миролюбів (по одному навесні та влітку), чотири зразки води, відібрані в с. Великий Дивлин (один - навесні, два - влітку, один восени), чотири зразки води, відібрані в с. Липники (по одному взимку та восени) і два зразки - влітку), чотири зразки в с. Червона Волока (по одному - навесні та восени) і два зразки - влітку).

Табл. 3. Кількість перевищень ДСанПІН 2.2.4-171-10

та ДСТУ 7525:2014 для азоту нітратного у пробах питної води Лугинського району в 2016 році $(n=5)$

\begin{tabular}{|l|c|c|c|c|}
\hline \multirow{2}{*}{ Назва населеного пункту } & \multicolumn{4}{|c|}{ Децентралізоване водопостачання } \\
\cline { 2 - 5 } & Зима & Весна & Літо & Осінь \\
\hline смт Лугини & - & 1 & 2 & 1 \\
\hline с. Миролюбів (Жовтневе) & - & 1 & 1 & - \\
\hline с. В. Дивлин & - & 1 & 2 & 1 \\
\hline с. Липники & 1 & - & 2 & 1 \\
\hline с. Червона Волока & - & 1 & 2 & 1 \\
\hline
\end{tabular}

У решті зразків колодязної води перевищень хоч $\mathrm{i}$ не виявлено, однак вміст нітратів був близьким до допустимої межі.

\section{Висновки}

1. Моніторингові дослідження проб питної води Лугинського р-ну Житомирської обл. на вміст хлоридів, сульфатів та нітратів 3 джерел централізованого і децентралізованого водопостачання свідчать, що ситуація не $\epsilon$ благополучною, хоча за вмістом хлоридів і сульфатів перевищення норм ДСанПІН 2.2.4-171-10 та ДСТУ 7525:2014 не виявлено.

2. За вмістом нітратів у воді, відібраної з колодязів, перевищення норм виявлено у всі досліджувані (2014-2015) роки. Це можна пояснити, передусім, низькою водністю річок, падінням рівня підгрунтових вод, i, як наслідок, низькою водністю джерел децентралізованого водопостачання через аномальну посуху, не характерну для Полісся.

3. У динаміці 2014-2016 рр. відбувається тенденція до збільшення вмісту всіх забруднювальних сполук, як у воді водогону, так і в колодязях.

4. 3 огляду на це, можна зробити загальний висновок, що за вмістом азотистих сполук вода джерел централізованого водопостачання менше піддається забрудненню, ніж вода джерел децентралізованого водопостачання. Без додаткового доочищення таку воду не можна рекомендувати для питного водопостачання.

\section{Перелік використаних джерел}

Blazhkevych, L. Y. (2018). Profilaktyka vodnonitratnoi methemohlobinemii u ditey rannoho viku na terytorii Ternopolskoi oblasti. Retrieved from: http://www.terses.gov.ua. [In Ukrainian].

Bobrovskyi, A. L. (2005). Hidroekosystemy: osnovni ponyattya $i$ pryntsypy. (In 1). Rivne, 319 p. [In Ukrainian].

DSTU ISO 4808. (2007). Dzherela tsentralizovanoho pytnoho vodopostachannia. Hihienichni ta ekolohichni vymohy shchodo yakosti vody i pravyla vybyrannya. [Sources of centralized drinking water supply. Hygienic and environmental requirements for water quality and selection rules]: from 01 Jan 2012. Kyiv: Derzhspozhyvstandart Ukrainy. 15 p. [In Ukrainian].
DSTU ISO 7525. (2014). Voda pytna. Vymohy ta metody kontroliuvannya yakosti. [Water is potable. Requirements and methods of quality control]: from 12 Jun 2018. Kyiv: Minekonomrozvytku Ukrainy. 30 p. [In Ukrainian]. Retrieved from: http://metrology.com.ua Fadeeva, V. K. (1972). Yzuchenye vlyianyia visokomyneralyzovannikh khlorydnikh pytevikh vod na sostoianye serdechno-sosudystoy systemi (eksperymentalnie y klynyko-fyzyolohycheskye yssledovaniya). [Study of the effect of highly mineralized chloride drinking water on the state of the cardiovascular system (experimental and clinical-physiological studies)]. Abstract of Candidate Dissertation for Biology Sciences. Moscow. 72 p. [In Russian].

HDK. (1991). Hranychno-dopustymi kontsentratsii (HDK) i oriientovani dopustymi rivni (ODR) shkidlyvykh rechovyn u vodi vodnykh obiektiv hospodarsko-pytnoho ta kulturno-pobutovoho vodokorystuvannya [Limit-permissible concentrations $(L P C)$ and oriented permissible levels $(O P L)$ of harmful substances in water of water objects of economic-drinking and cultural and household water use]: zatv. Minzdravom SRSR vid 21.10.91 p., № 6025. URL: http://zakon.rada.gov.ua. [In Ukrainian].

Holian, V. (2017). Ukrayna na hrany ekolohycheskoho bedstviya: vodokhozyaistvennie problemi usuhublyayutsa. [Ukraine is on the verge of ecological disaster: water management challenges are exacerbated]. URL: http://vgolian.com/ukraina-na-grani-ekologicheskogo-bedstviya. [In Ukrainian].

Honcharuk, V. V. (2018). Osobennosty proishozhdeniya vody na planete Zemlya. Novie podkhody $\mathrm{k}$ otsenke kachestva vody. [Features of the origin of water on the planet Earth. New approaches to water quality assessment]. Khymyia y tekhnolohyi vodi, 40(1), 3-22.

Honcharuk, V. V., Tarletska, A. V., Zui, O. V., Pshynko, H. N., \& Saprykyna, M. N. (2018). Pryntsypyalno novaya tekhnolohiya podhotovky vodoprovodnoy vody sanytarno-hyhyenycheskoho naznacheniya. [A fundamentally new technology for the preparation of tap water for sanitation and hygiene purposes]. Khymiya y tekhnolohyi vody, 40(1), 22-32. [In Ukrainian].

GOST 18826-73. (2003). Voda pytevaya. Metody opredeleniya soderzhaniya nytratov [Drinking water. Methods for determination of mineral nitrogen-containing substances]. Vved. 1974-01-01. GOST 18826-73. Moscow: Yzd-vo standartov. 7 p. [In Russian].

GOST 4192-82. (2003). Voda pytevaya. Metody opredeleniya myneralnykh azotosoderzhashchykh veshchestv. [Drinking water. Methods for determination of mineral nitrogen-containing substances]. Vved. 1983-01-01. Moscow: Yzd-vo standartov. 7 p. [In Russian].

GOST 4245-72. (2003). Metody opredeleniya soderzhaniya khlorydov. Metod tytrometrycheskiy [Methods for determination of chloride content. Titrometric method]. Vved. 1974-01-01. GOST 18826-73. Moscow: Yzd-vo standartov. 6 p. [In Russian]

GOST 4389-72. (2003). Metody opredeleniya sulfatov. Metod turbydymetrycheskiy [Methods for the determination of sulfates. Method turbidimetric]. Vved. 1974-01-01. GOST 18826-73. Moscow: Yzd-vo standartov. 9 p. [In Russian].

Hryhorenko, L. V., Shevchenko, O. A., \& Dziak, M. V. (2012). Vmist heokhimichnykh elementiv u pytniy vodi pidzemnykh dzherel vodopostachannya ta naslidky dlya zdorovya naselennya. Khvoroby vodnoi etiolohii yak hihiienichna problema. [Content of geochemical elements in drinking water of underground water sources and consequences for public health. Diseases of water etiology as a hygienic problem]. Hihiiena naselenykh mists, 59, 74-79.

Hygienic requirements. (2010). Pro zatverdzhennya Derzhavnykh sanitarnykh norm ta pravyl "Hihienichni vymohy do vody pytnoi, pryznachenoi dlya spozhyvannya liudynoyu" [On Approval of State Sanitary Norms and Rules. "Hygienic requirements for drinking water intended for human consumption"]: nakaz M-va okhorony zdorovya Ukrainy vid 12 trav. 2010 p., № 400. URL: http://zakon3.rada.gov.ua/laws/show/z0452-10 (data zvernennia: 29.11.2017). [In Ukrainian].

Khilchenko, L. (2018). Nitraty u pytni vody - nebezpeka dlya ditey ta doroslykh. [Nitrates in drinking water are a danger to children and adults]. Retrieved from: http://alnews.com.ua. [In Ukrainian].

Korotun, O. (2018). Nitraty u pytnii vodi - nebezpeka dlya ditei ta doroslykh. [Nitrates in drinking water are a danger to children and adults]. Retrieved from: https://www.bsmu.edu.ua. [In Ukrainian]. 
Kotkova, T. M., Seleznova, H. O., \& Kotkov, V. I. (2011). Monitorynh zabrudnennya spolukamy azotu richok Luhynskoho rayonu Zhytomyrskoi oblasti. [Monitoring of the pollution of Zhytomir oblast Lugyny district rivers with nitrogen compounds]. Visnyk Zhytomyrskoho natsionalnoho ahroekolohichnoho universytetu, 2(2), 144-150. [In Ukrainian].

Kotkova, T. M., Seleznova, H. O., \& Yurchuk, T. O. (2013). Ekolohichna otsinka dzherel pytnoho vodopostachannya Luhynskoho raionu Zhytomyrskoi oblasti. [Ecological estimation contend in drinking water sources in water supply in luginy region Zhytomyr oblast]. Voda: problemy ta shliakhy vyrishennia: Materialy IV Vseukrainskoi naukovo-praktychnoyi konferentsiyi, (pp. 70-76). Rivne, July 4-7. [In Ukrainian].

Lure, Yu. Yu. (Ed.). (1973). Unyfytsyrovannye metodi analyza vod. [Unified methods of water analysis]. Moscow: Khymyia. [In Russian].

Maliarenko, V. V. (2014). Vodnaya evrointehratsyia Ukrayni. [Water European integration of Ukraine]. Voda y vodoochystytelnie tekhnolohyy, 2, 28-31. [In Ukrainian].

Methemoglobinemia. (2018). Methemohlobinemiya - zakhvoriuvannya, yake kharakteryzuietsya pidvyshchenym rivnem methemohlobinu v krovi. [Methemoglobinemia is a disease characterized by elevated levels of methemoglobin in the blood]. Retrieved from: oblses-kiev.com.ua. [In Ukrainian].
National Report. (2011). Natsionalna dopovid pro yakist pytnoi vody ta stan pytnoho vodopostachannya v Ukraini u 2010 rotsi [The National Report on the Quality of Drinking Water and the State of Drinking Water Supply in Ukraine in 2010 year]. Ministerstvo rehionalnoho rozvytku, budivnytstva ta zhytlovo-komunalnoho hospodarstva Ukrainy. Kyiv. 564 p. [In Ukrainian].

Rilova, N. V. (2002). Prohnozyrovanye, rannyaya dyahnostyka y korrektsyia hastroduodenalnoi patolohyy u detei, upotreblyayushchykh sylnomyneralyzovannuiu pytevuyu vodu s visokym soderzhanyem sulfatov. [Forecasting, early diagnosis and correction of gastroduodenal pathology in children who drink highly mineralized drinking water with high sulfate content]. Abstract of Candidate Dissertation for Medical Sciences. Kazan, 18 p. [In Russian].

Schadstoffe. (2018). Nähr- und Schadstoffe. Retrieved from: https://www.umweltbundesamt.de. [In Germany].

Shkrabliuk, K. V. (2018). Nitraty v pytniy vodi smertelno nebezpechni. [Nitrates in drinking water are mortally dangerous]. Retrieved from: http://krasyliv-rda.org.ua. [In Ukrainian].

Trinkwasser. (2018). Schadstoffe im Trinkwasser. Retrieved from: https://www.wasserklinik.com/schadstoffe-im-trinkwasser. [In Germany].

Wasser. (2018). Nitrat im Wasser - so Gefährlich ist Nitrat im Trinkwasser wirklich. Retrieved from: https://www.wassertest-online.de. [In Germany].

Т. Н. Коткова, Н. И. Федючка, И. Ф. Карась

Житомирский национальный агроэкологический университет, м. Житомир, Украина

ЭКОЛОГИЧЕСКАЯ ОЦЕНКА ПИТЬЕВОЙ ВОДЫ ЛУГИНСКОГО РАЙОНА ЖИТОМИРСКОЙ ОБЛАСТИ НА СОДЕРЖАНИЕ ХЛОРИДОВ, СУЛЬФАТОВ И НИТРАТОВ

Проведена экологическая оценка состояния воды водопроводов и колодцев Лугинского района Житомирской области на содержание хлоридов, сульфатов та нитратов. Проведен мониторинг ситуации в тех населенных пунктах, где есть и водопровод, и колодцы. Сюда принадлежат пгт Лугины, села Великий Дивлин, Липники, Червона Волока, Миролюбов (старое название Жовтневе). Проведено ряд исследований за 2014, 2015, 2016 гг. В динамике исследованных годов наблюдается тенденция к увеличению содержания загрязнителей группы кислотных остатков как в источниках централизованного, так и децентрализованного водоснабжения. Другой установленной закономерностью оказалось увеличенное содержание всех исследованных загрязнителей в колодцах сравнительно с водопроводами. Однако, если по хлоридам и сульфатам превышений норм ДСанПІН 2.2.4-171-10 не обнаружено, то содержание нитратов в некоторых исследованных образцах был выше нормы в течение всех лет. Объяснить ситуацию можно уменьшением водности рек в течение последних лет и снижением уровня подземных вод, что приводит к увеличению концентрации всех загрязняющих веществ, в том числе и нитратов. Особенно критической ситуация была летом 2016 г. В колодцах некоторых хозяев вода отсутствовала вообще. Итак, нельзя утверждать, что ситуация с питьевым водоснабжением Лугинского района Житомирской области есть безопасной. В засушливые годы, а именно такими и были исследованные нами, наблюдаются вспышки загрязнения питьевой воды нитратами.

Ключевые слова: загрязнение воды; государственные санитарные нормы; ДСТУ 7525:2014; источники централизованного водоснабжения; источники децентрализованного водоснабжения; колодезная вода; водопроводная вода.

T. N. Kotkova, N. I. Fedjuchka, I. F. Karas

Zhytomyr National Agroecological University, Zhytomir, Ukraine

\section{ENVIRONMENTAL ASSESSMENT OF DRINKING WATER IN LUHYNY DISTRICT OF ZHYTOMYR REGION ON CHLORIDES, SULPHATES AND NITRATES CONTENT}

The environmental assessment of the water state from pipes and wells in Luhyny district of Zhytomyr Region on the chlorides, sulphates and nitrates content is carried out. The situation is monitored in those settlements where there are both water pipes and wells. These include the town of Luhyny, villages of Great Dyvlyn, Lypnyky, Chervona Voloka, Myrolyubiv (the old name is Zhovtneve). During 2014, 2015 and 2016 years a series of studies was carried out. In the dynamics there is a tendency to increasing of content of contaminants of the acid residue group both in the sources of centralized and decentralized water supply. The second established regularity was content increasing of all investigated pollutants in wells in comparison with water pipes. During water decontamination by chlorine thousands of super-toxic compounds are formed and the most dangerous are organochlorine, which, in addition to pronounced toxicity, have mutagenic and carcinogenic properties. Further purification with activated charcoal does not remove all of them. As for the high nitrates content, this leads to water-nitrate methemoglobinemia. Water-nitrate methemoglobinemia is caused by the toxic effect of nitrates that leads to oxygen fasting of tissues (hypoxia), violation of oxygen transport by blood and suppressing the activity of enzyme systems involved in the processes of tissue respiration. However, if chlorides and sulphates content didn't exceed DSanPiN 2.2.4-171-10, then the content of nitrates in some of the samples was over the norm during all studied years. Consequently, it cannot be argued that the situation with drinking water supply in Luhyny district of Zhytomyr region is safe. In arid years, these were investigated ones, there were flares of drinking water pollution by nitrates. In the process of research the field (sampling of water) and laboratory (studying of the compounds content in samples) methods were used. To determine the amount of investigated compounds in water samples standard methods were used, particularly the methods of the determination of nitrogencontaining substances, the methods of nitrates determination (GOST 18826-73), the methods of chlorides content determining (GOST 4245-72), and also methods of sulfates determination (GOST 4389-72).

Keywords: water pollution; chlorides; chlorides content in water; sulfates; sulfates content in drinking water; nitrates; nitrates content in water; state sanitary norms; DSTU 7525:2014; sources of centralized water supply; sources of decentralized water supply. 